\title{
Anthropogenic organic micro-pollutants and pathogens in the urban water cycle: assessment, barriers and risk communication (ASKURIS)
}

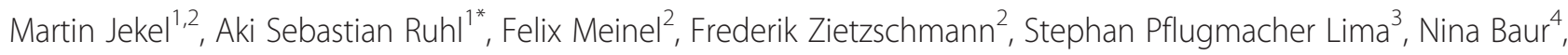
Melanie Wenzel ${ }^{4}$, Regina Gnir $\beta^{5}$, Alexander Sperlich ${ }^{5}$, Uwe Dünnbier ${ }^{6}$, Uta Böckelmann ${ }^{6}$, Daniel Hummelt ${ }^{6}$, Patricia van Baar ${ }^{6}$, Florian Wode ${ }^{6}$, Dietmar Petersohn ${ }^{7}$, Tamara Grummt ${ }^{8}$, Alexander Eckhardt ${ }^{8}$, Wolfgang Schulz ${ }^{9}$, Alexandra Heermann ${ }^{9}$, Thorsten Reemtsma ${ }^{10}$, Bettina Seiwert ${ }^{10}$, Linda Schlittenbauer ${ }^{10}$, Boris Lesjean ${ }^{11}$, Ulf Miehe ${ }^{11}$, Christian Remy ${ }^{11}$, Michael Stapf ${ }^{11}$ and Daniel Mutz ${ }^{11}$

\begin{abstract}
In urban areas, water often flows along a partially closed water cycle in which treated municipal wastewater is discharged into surface waters which are one source of raw waters used for drinking water supply. A number of organic micro-pollutants (OMP) can be found in different water compartments. In the near future, climatic and demographic changes will probably contribute to an increase of OMP and antibiotic-resistant pathogens in aquatic ecosystems. The occurrence of OMP, possible adverse effects on aquatic organisms and human health and the public perception must be carefully assessed to properly manage and communicate potentially associated risks and to implement appropriate advanced treatment options at the optimum location within the water cycle. Therefore, the interdisciplinary research project ASKURIS focuses on identification and quantification, toxicological assessment and removal of organic micro-pollutants and antibiotic-resistant pathogens in the Berlin water cycle, life cycle-based economic and environmental assessment, public perception and management of potential risks.
\end{abstract}

Keywords: Organic micro-pollutants; Anthropogenic trace compounds; Non-target mass spectrometry; Pathogens; Human bio-monitoring; Toxicological assessment; Advanced wastewater treatment; Activated carbon adsorption; Ozonation; Risk perception

\section{Review}

\section{Background}

Due to the widespread use of chemicals and to the fast advances in analytical methods, a large number of organic micro-pollutants (OMP) can be detected nowadays in wastewater and in the aquatic environment [1]. Pharmaceuticals are of special interest since they exert biologic effects by intention and partly unavoidable side effects [2]. Many OMP are efficiently removed in conventional wastewater treatment processes, but a number of polar OMP persist the biological treatment [3-6]. Persistent compounds are released into surface water and can be

\footnotetext{
* Correspondence: aki.s.ruhl@tu-berlin.de

${ }^{1}$ Technische Universität Berlin, Centre for Water in Urban Areas, Straße des 17. Juni 135, Berlin 10623, Germany

Full list of author information is available at the end of the article
}

detected there [7] and in groundwater [8,9]. Some compounds are efficiently removed during bank filtration $[10,11]$. Some OMP persist during drinking water treatment $[12,13]$.

Technical advances in analytical methods enable the identification of low trace concentrations of known or even unknown OMP in the aquatic environment. Extensive knowledge about occurrence and fate of relevant OMP in the aquatic environment is mandatory for the successful implementation of technological measures. However, in Europe, no regulatory limits for pharmaceutically active OMP in surface water or drinking water have come into force hitherto, notwithstanding pharmacovigilance.

Additional treatment steps are required in order to reduce the release of OMP into the aquatic environment. Adsorption of OMP onto activated carbon is one promising 
option $[14,15]$. Oxidation using ozone is another powerful technique for the OMP removal from wastewater treatment plant effluents [16-19]. Possible by-products are a potential drawback of ozonation [20,21]. Moreover, each additional treatment step requires energy and resources and thus causes additional impacts on the environment [22,23].

Besides OMP, antibiotic-resistant microorganisms can be found in different parts of an urban water cycle [24]. Infections caused by multi-resistant germs became a severe issue due to the widespread application of antibiotics $[25,26]$.

\section{Situation in Berlin and ASKURIS}

Surface water and drinking water sources in Berlin are embedded in partially closed water cycles. Some recalcitrant OMP are released into surface water together with treated wastewater of eight treatment plants, and certain compounds can be detected in different compartments of the Berlin water cycle [27-29]. The climatic and demographic developments will presumably lead to further increased OMP concentrations in the near future [30].

The water cycle around Lake Tegel as shown in Figure 1 is an ideal study site for urban water cycles. The effluent from the wastewater treatment plant in Schönerlinde is released into the Nordgraben channel that confluences with the river Tegeler Fließ. Subsequently, the water is treated in the phosphorus elimination plant (PEP) in Tegel [31]. A pipeline connecting the outlet of Lake Tegel into the river Havel (pumping station) with the PEP Tegel is used to pump additional surface water to the phosphorus elimination plant to increase the flow rate in Lake Tegel in the summer period. Modelling of different pumping scenarios with regard to phosphorus and OMP removal revealed that additional treatment processes are required [32]. Lake Tegel is used as bathing water, and wells around the lake are used for drinking water supply with bank filtration.

The joint research project ASKURIS as part of the funding measure RiSKWa [33] aims at the identification

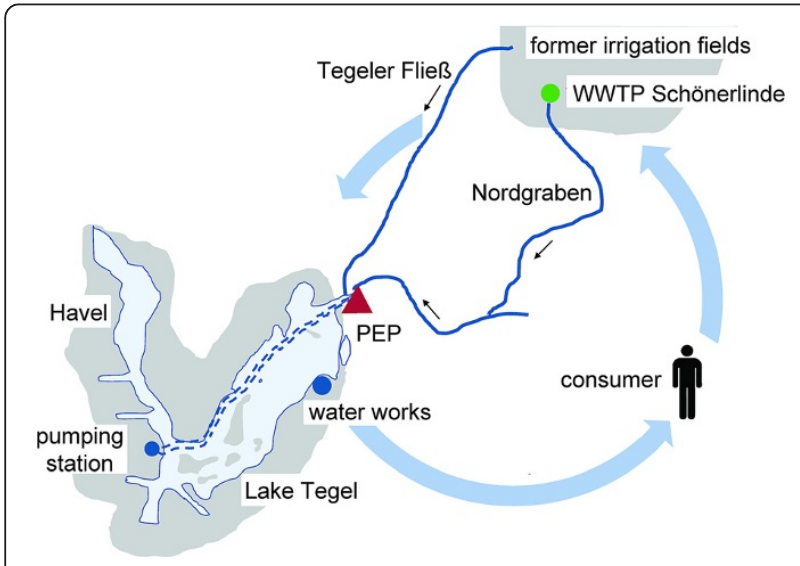

Figure 1 Urban water cycle around Lake Tegel in Berlin. and quantification of both known and unknown OMP and resistant microorganisms in the urban water cycle, particularly around Lake Tegel. Methods for the analyses of both known (target) and unknown (non-target) OMP with high-resolution mass spectrometers are being developed and applied. Antibiotic-resistant microorganisms are identified with conventional and molecular-biological techniques, and the degree of resistance is being investigated.

In order to assess the safety for humans and the environment, samples from various segments of the water cycle are tested for both eco- and human toxicological impacts. The uptake and fate of OMP in the human body is in the focus of a human biomonitoring.

Engineered barriers for OMP are investigated in laboratory, pilot and full scale. The main focus is on adsorptive removal with powdered or granular activated carbon and oxidative removal with ozone. Especially, the ozone-treated water is intensively tested for eco- and human toxicity. Both economic and ecologic conditions of the innovative treatment options are assessed in detail to support decision making.

The actual, scientifically determined risk and the subjective perception of a hazard are not identical in many cases. The media play a pivotal role in communicating hazards and corresponding risks. The perception of OMP and associated risks in the public are also in the focus of ASKURIS. Results from ASKURIS will be transferred to the risk management of Europe's largest integrated water supplier and wastewater disposer.

\section{Occurrence and fate of OMP and resistant microorganisms OMP quantification}

Due to the large number of OMP in use and thus discharged to wastewater and to the aquatic environment, fast and reliable analytical methods for a multiplicity of OMP are required. Multi-residue methods with preliminary extraction have been developed for a simultaneous analysis of multiple targets [34]. Advanced analytical systems facilitate direct sample injection [35] with advantages regarding expenditure of time and costs. For example, a wide range of 150 pesticides have been successfully covered within one method [36].

In ASKURIS, multi-residue methods for ultrahigh performance liquid chromatography with high-resolution mass spectrometry are being developed and successfully applied to aqueous samples of various origins [37].

\section{Identification of unknown OMP}

Besides the known compounds, a wide range of anthropogenic organic substances and their transformation products occur in the aquatic environment. In order to identify compounds not included in multi-residue methods, the so called non-target screening has been shown to be a 
powerful method to identify or even track the pathway of individual compounds [38]. A full scan mass spectrometer with high resolution and mass accuracy is a prerequisite for that purpose.

Two different strategies are possible [39]: (1) in suspects screening, also called 'known-unknown screening', each detected mass ('unknown') in the highly resolved spectrum is compared to a list of predefined substances ('known'). (2) In non-target screening, peaks with defined masses are extracted from the spectrum and online databases are searched for substances of the specific mass. For that purpose, the database DAIOS (databaseassisted identification of organic substances) has been created and already successfully applied for the identification of trace organic compounds [38]. An exemplary input mask is shown in Figure 2. The DAIOS database currently contains approximately 1,400 individual compounds and will be further extended.

\section{Multi-resistant microorganisms}

Molecular microbiological methods are applied in ASKURIS in order to investigate the occurrence of antibiotic-resistance genes [40]. Besides the well-known multi-antibiotic-resistant Staphylococcus, multi-antibioticresistant intestine bacteria such as Citrobacter, Enterobacter and Escherichia coli have been detected [41,42]. Enterococci with resistance against vancomycin $[43,44]$ and multiantibiotic-resistant Pseudomonas aeruginosa [45] have been found.

The gene tet(M), for example, is involved in the resistance towards the antibiotic tetracycline and has been found in wastewater treatment plants and their effluents [46]. Quantitative real-time polymerase chain reaction (RTPCR) is applied to search for tet(M) in samples from the water cycle including treated wastewater, effluent of the phosphor elimination plant, surface water, bank filtrate and drinking water and, additionally, hospital effluents.

Besides RT-PCR, conventional cultivation methods are applied. Antibiograms are utilized to track for resistance of microorganisms towards different antibiotics. A number of specific resistances have been found in river water and water wells using antibiograms for a drinking water source [47]. Selected bacteria are specifically enriched on selective agar plates (cetrimide agar, Chromocult agar, among others) and subsequently exposed to antibiotics.

\section{Water safety \\ Human toxicology}

The risk assessment in ASKURIS emphasizes the relevance for humans. Cell-based assays are used to test for potential genotoxic risks. Since assessing genotoxicity is focused on the micronucleus assay, microscopy as well as cytometry for counting micro-nuclei is employed.

In addition to genotoxicity tests, cytotoxic potentials are also assessed, thereby differentiating between necrosis and apoptosis. This is accomplished by measuring the release of lactate dehydrogenase and changes in the electric resistance of the cells. Both methods indicate necrosis, whereas apoptosis is assessed via the detection of released nucleosomes. Furthermore, fluorescence analysis is used for determining the intracellular generation of reactive oxygen species. These tests are accompanied by the quantification of epigenetic changes like the activation of NF- $\mathrm{kB}$, thus accounting for genotoxic precursor mechanisms.

The assessment of the relevance for humans is achieved by conducting these experiments in parallel to tests using well-established human cancer cell lines and

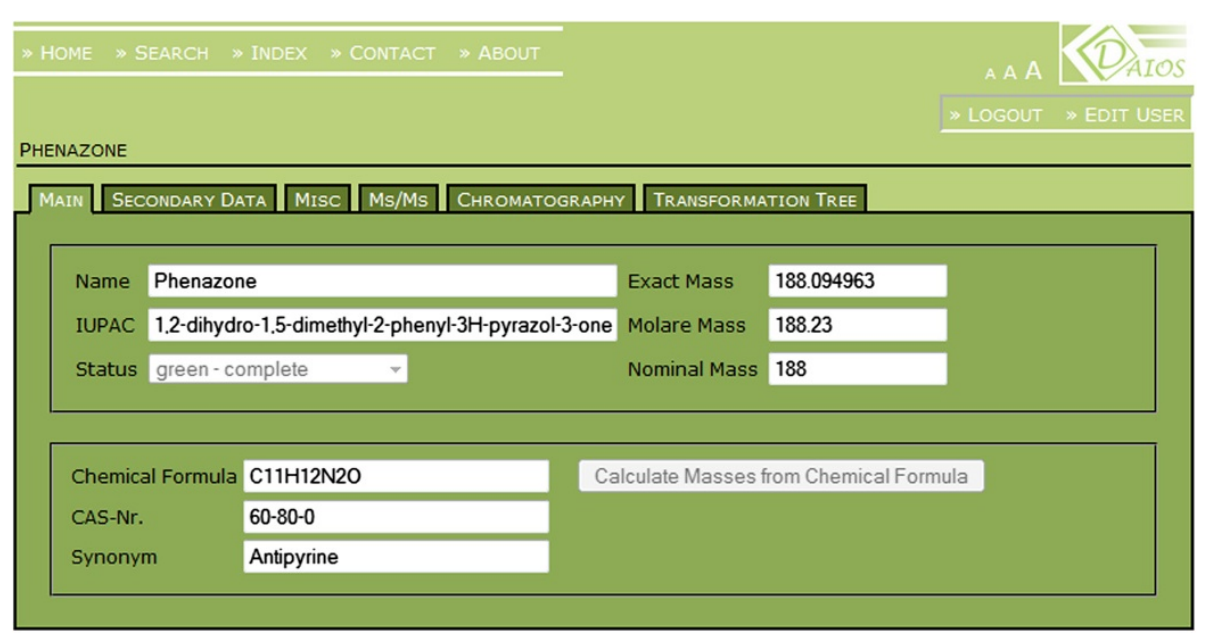

Figure 2 Exemplary screenshot showing the graphical user interface of the online database DAIOS. With input fields for the OMP name, the IUPAC name, the exact, molar and nominal masses, the chemical formula, CAS number and synonyms (courtesy of www.DAIOS-online.de). 
primary human cells. Based on the pivotal role of the liver in metabolizing xenobiotics, the experiments are focused on hepatocytes. The comparative tests are mainly carried out in the cell line HepaRG ${ }^{\mathrm{mm}}\left(\mathrm{Gibco}^{\circ}\right)$ and in primary human hepatocytes.

\section{Ecotoxicology}

Both original samples from the Berlin water cycle as complex mixtures and OMP solutions are tested for ecotoxicological effect potentials. On the one hand, standardized bioassays are applied in ASKURIS, e.g. Daphnia immortality (ISO 6341:1996, DIN 38412-30:1989-03) and Aliivibrio fischeri bioluminescence (ISO 11348-3:2007, DIN 3841237:1999-04). The conventional tests are based on mortality rates or growth inhibition after short-term exposure. Acetylcholinesterase inhibition (DIN 34815-1:1995-02) is applied for neurotoxic effects, and the UmuC test (ISO 13829:2000, DIN 38415-3:1996-12) gives information about genotoxic effects. On the other hand, a novel biotest with macrophytes (Myriophyllum spicatum) is used to assess different physiological parameters such as biotransformation enzymes (glutathione S-transferase) and enzymes for the mitigation of oxidative stress (peroxidase or superoxide dismutase). Enzymes are quantified and gene expressions are investigated using respective primers and quantitative RT-PCR.

The combination of conventional and novel test systems enables an appropriate assessment of the risks for the aquatic environment.

\section{Human biomonitoring}

As outlined in Figure 1, humans are an essential part of the urban water cycle and water treatment aims at avoiding or minimizing the exposure of humans to OMP via drinking water. However, humans are exposed to chemicals in many ways, e.g. in their homes, at work or via food. Human biomonitoring by means of OMP measurements in urine samples provides information on the extent to which humans are exposed to chemicals. Monitoring of human urine also indicates to which extent humans are a source of OMP found in municipal wastewater. For human biomonitoring, it is essential to consider also metabolites of OMP as recently shown for trialkyl phosphates [48].

In ASKURIS, multi-residue mass spectrometric methods are being developed and used to determine the human exposure to OMP and to assess their importance as a source of OMP in wastewater.

\section{OMP removal \\ Laboratory investigation of powdered and granular activated carbon}

In ASKURIS, various processes involving activated carbon for OMP removal are tested on several scales. A large number of activated carbon products are available as powders or granules. On the lab scale, different activated carbon products are checked for their feasibility and efficiency in OMP reduction from different water matrices. The tests include powdered activated carbon (PAC) as well as granular activated carbon (GAC) products. For the comparison of different PAC, varying doses of the products are added to the respective water, and OMP adsorb onto the activated carbons during variable adsorption times [49]. This kind of testing can also be conducted with GAC which is pulverized by milling prior to testing.

Besides the tests with milled products, defined fractions obtained from sieving milled GAC are investigated. The sieved fractions are then used as filter materials in defined rapid small-scale column tests (RSSCT) that are designed to comply with the hydraulic dimensioning of large filters used in pilot or full-scale applications. The RSSCT design allows for quick and hydraulically realistic conditions during testing [50,51]. One drawback of the RSSCT method is that during milling, the external surface of the GAC is increased due to the production of smaller GAC particles (the internal surface which determines the adsorption capacity for OMP is only affected insignificantly) [52]. Effluents from wastewater treatment plants contain effluent organic matter besides natural background organic matter (e.g. humic and fulvic substances). It has been shown that different fractions of the dissolved organic carbon (with regard to size exclusion chromatography and online organic carbon detection) can be removed by adsorption onto powdered activated carbon [53]. Large organic molecules are able to block activated carbon pores and therefore potentially reduce the OMP adsorption capacity. Large molecules therefore might cause more adverse blockage on large GAC particles (with small external surface) compared to small GAC particles (with larger external surface). Thus, blockage by large organic molecules can be more pronounced when using original GAC than when using ground GAC. Therefore, GAC products are also tested in their original delivery condition.

\section{Adsorptive OMP removal in pilot scale}

In a first pilot phase, a rapid dual-media filtration with GAC and sand has been examined, subsequent to phosphorus precipitation and sedimentation in the PEP Tegel. The pilot filters as shown in Figure 3 comprise of two filter columns (300 $\mathrm{mm}$ inner diameter) operated in parallel with a fully automated backwash process. One column was filled with GAC and sand while the other (filled with pumice) served as a reference. The filter velocity was $8.5 \mathrm{~m} / \mathrm{h}$, and the duration of the first pilot phase was 110 days which resulted in a total of 11,530 bed volumes or $24.45 \mathrm{~m}^{3} / \mathrm{kg}$ GAC. 


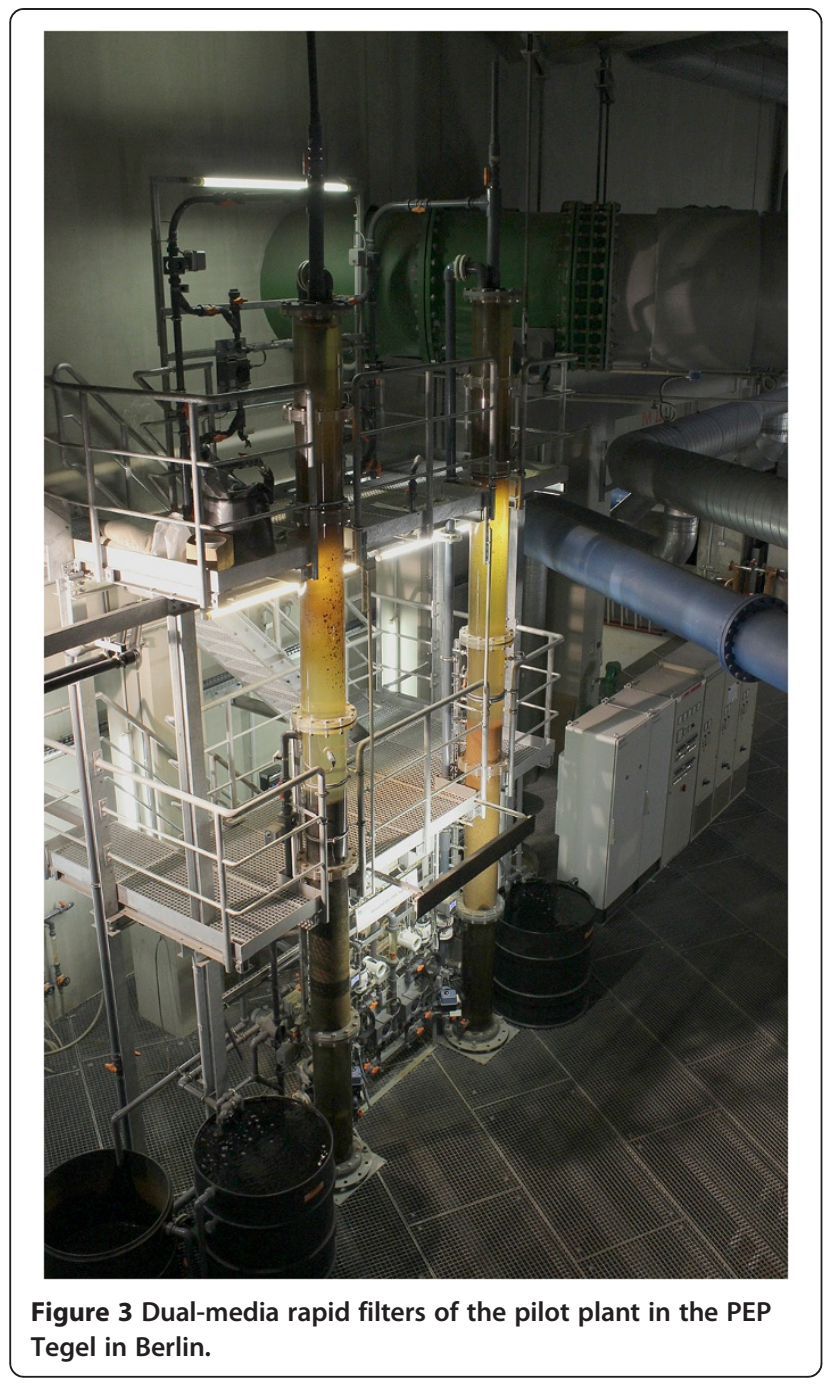

Results show that the filter performance of the GAC filter was equal to the reference representing the setup of the large-scale plant. Phosphorus removal was almost equal to the reference filter resulting in mean concentrations of 16 and $17 \mu \mathrm{g} / \mathrm{L}$. Likewise, parameters such as dissolved organic carbon (DOC), total suspended solids, UV light absorption at $254 \mathrm{~nm}$ wavelength, turbidity and colour values showed no significant difference between the two filters.

In a second phase, a pilot plant with PAC dosage and coagulation/precipitation, flocculation, sedimentation and filtration is operated. A mean flow of $1,350 \mathrm{~L} / \mathrm{h}$ surface water (influenced by wastewater) is withdrawn from the influent of the PEP Tegel. PAC and coagulant are dosed in front of a motionless mixer. In a three-stage mixing cascade, adsorption of OMP onto PAC and coagulation of particles take place simultaneously. Flocks are settled in an enhanced clarifier, and the sludge containing a high amount of PAC is recirculated back into the mixing cascade. Surplus sludge is removed. Two parallel rapid dual- media filtration units (anthracite or pumice and sand) are operated downstream.

Optimal conditions for phosphor and OMP removal are to be found meeting the specific requirements of the Berlin water cycle. Two-stage coagulation and adsorption as well as comparative investigation of different filter media are in the focus of work.

\section{Oxidative OMP removal with ozone}

As activated carbon or ozonation processes are both viable options for the removal of OMP, ozonation is tested as well for the treatment of wastewater treatment plant effluent. The removal of OMP is tested for a dosing range between 0.5 and $0.8 \mathrm{mg} \mathrm{O}_{3} / \mathrm{mg}$ DOC under dynamic operational conditions including, e.g. storm weather events.

For the removal of (possibly toxic) by-products from the oxidation step and to degrade the readily bioavailable DOC after ozonation, three filters are tested for posttreatment. Dual-media and biological activated carbon filtration are compared regarding the degradation of OMP, nitrification performance, and the diminishment of effect potentials observed in bioassays. Besides the biological activity, treatment benefits from the remaining adsorption capacity of the activated carbon filter will be evaluated. An additional slow sand filter after the dual media filter simulates artificial groundwater recharge, targeting for the worst case condition of direct infiltration of waste water treatment plant effluent.

\section{Economic and environmental assessment in a life cycle perspective}

Additional treatment processes for elimination of OMP or pathogenic microorganisms require resources such as infrastructure, chemicals and energy, thus causing associated impacts on the environment for the supply of these resources and also additional costs for water utilities. The selection of an appropriate technology and the positioning of the treatment step within the urban water cycle both influence the overall efficiency of the process, the related costs and the environmental impacts. Hence, a comprehensive analysis of all associated environmental and economic impacts is required for supporting the decision for a specific technology or appropriate location of treatment.

In ASKURIS, environmental and economic assessment is based on the holistic approach of life cycle thinking, taking into account all direct and indirect effects of the investigated system on upstream or downstream processes. The system under study will encompass the urban water cycle at Lake Tegel in Berlin (compare Figure 1) as a case study for water management in densely populated urban areas. For environmental impacts, different technological options and strategies of removing OMP and pathogens will be 
compared with Life Cycle Assessment (LCA), building upon the existing methodological framework of ISO 14040/44. For economic implications, total costs of these scenarios will be calculated in terms of both investment and operating costs. Results of LCA and cost analysis will then be used to identify pros and cons of technological and strategic options and give decision support for future implementation of additional treatment processes at the respective sites.

\section{Large-scale tests}

The pilot scale studies together with the economic and ecologic assessments will support the choice of the best available technology for OMP removal within the Berlin water cycle. The technical option with the most promising results from pilot scale investigations is planned to be implemented in full-scale within ASKURIS.

\section{Risk perception and risk management The discursive construction of risk}

From a sociological point of view, the public discussion and dispute about the existence and extent of risks of anthropogenic OMP and pathogens in drinking and surface water takes place in public or semi-public discourses. These discourses influence how we perceive possible risks, how we think about possible risks, what risks we state as true or false and finally, how we act and behave in everyday life and in times of risk-based uncertainty and crisis [54-58]. Hence, a basic assumption in regard to a sociological perspective is the constructive approach in the tradition of Berger and Luckmann [59]. Discourses can be understood as social practices of producing, reproducing and stabilizing social reality [55]. These practices are usually controversial and conflictive; moreover, they are always guided by specific interests of the regarding social actors as representatives of specific interest groups.

With respect to the particular research focus in ASKURIS, discourses about the existence and extent of risks of anthropogenic OMP and pathogens in the drinking and surface water occur in and in-between different discourse fields: (1) in mass media; (2) in general public, in terms of the 'normal' consumer of water in everyday life; furthermore, in specialized areas like (3) topicrelated sciences (engineering, biology, toxicology, ecology, medicine etc.); (4) politics; and (5) water suppliers and their representatives. Our research aim is it to analyse how the knowledge about and attitude towards the existence and extent of these risks are being produced in the mentioned discourses above and how these discursively produced and constructed 'truths' affect social actors.

In order to achieve these aims, an extensive survey is being conducted to cover these different discourse fields and to explore how risks of anthropogenic trace organic compounds and pathogens in the drinking and surface water are produced in and in-between these fields, which discourses are most powerful and dominant and why. Essential analytical categories will be the different lines of arguments, the various levels of the discourses and the diverse discourse positions [60]. Methods of qualitative content analysis will be used to extract these categories from our empirical data. These data include in-depth qualitative interviews with normal consumers and professionals from science, industry and politics; press articles, TV and radio broadcasts of regional and national media institutions and also published texts and documents from scientific, political, non-profit, charitable, educational and economical organisations.

\section{Risk management}

A further goal of ASKURIS is the transfer of the project's results into an integrated risk assessment for the water supply of Berliner Wasserbetriebe that both provides drinking water to 3.7 million people and treats the wastewater. The transfer includes occurrence and fate of OMP and pathogens within the urban water cycle, their toxicity, their relevance for human health and the assessment of different removal options. At the moment, the risk management system in place at Berliner Wasserbetriebe identifies, quantifies and evaluates business and organizational risks. Technical, economical and regulatory risks are thus included in the management process. Regarding water quality, compliance with all water quality and wastewater treatment standards is assured and the generally acknowledged technical codes of good practice are used. However, up to now, there is no holistic, process-orientated and risk-based approach which focuses on the whole urban water cycle.

The water safety plan (WSP) approach [61] of the World Health Organization offers a comprehensive framework to implement such an integrated management system to ensure water quality through good practice. Within ASKURIS, a WSP will be developed and implemented at Berliner Wasserbetriebe in three parts. First, a WSP for Berlin water works including supply system description, definition of critical control points, hazard analysis and risk assessments as well as development of control measures will be developed and implemented. In a second step, the WSP will be extended to include the urban water cycle, i.e. assessing the influence of the share of treated wastewater in surface water, combined sewer overflows, etc. on the water resource. Finally, the WSP will be extended to the drinking water distribution system. Besides compilation of partly already existing water supply system descriptions, the key activities in this work package are the scientific risk assessment for microbiological and chemical risks. Monitoring results as well as toxicological data for 
risk assessment obtained within ASKURIS will be used by a multi-disciplinary team including managers, engineers, water quality controllers and technical staff. The developed water quality related, integrated risk management system based on the water safety plan approach will then be integrated into the existing risk management system of Berliner Wasserbetriebe.

\section{Conclusions}

OMP and antibiotic-resistant organisms in the urban water cycle of Berlin are analyzed together with toxicological assessments and a human biomonitoring. This approach facilitates a scientific assessment of corresponding risks in urban areas. Different treatment options at different places within the water cycle are tested from bench scale up to large scale. Accompanying cost and life cycle assessments support the selection of most efficient technical measures with regards to the removal of harmful OMP and organisms and thus minimizes risk. A basis for an appropriate communication of potential risks is supported by an extensive sociological survey of the perception of OMP-related risks. The detailed scientific assessment of risks is used to implement a risk management system. Outcomes of the research project ASKURIS will provide an aid to decision-making for preventive measures against possible actual or future risks emanating from OMP and antibiotic-resistant microorganisms.

\section{Competing interests}

The authors declare that they have no competing interests.

\section{Authors' contributions}

All authors (MJ, ASR, FM, FZ, SPL, NB, MW, RG, AS, UD, UB, DH, PVB, FW, DP, $\mathrm{TG}, \mathrm{AE}, \mathrm{WS}, \mathrm{AH}, \mathrm{TR}, \mathrm{BS}, \mathrm{LS}, \mathrm{BL}, \mathrm{UM}, \mathrm{CR}, \mathrm{MS}$ and $\mathrm{DM})$ cooperate in the project ASKURIS and contributed to the manuscript. All authors read and approved the final manuscript.

\section{Acknowledgements}

The project ASKURIS is supported by the Federal Ministry of Education and Research (BMBF) within the funding measure RiSKWa.

\section{Author details}

${ }^{1}$ Technische Universität Berlin, Centre for Water in Urban Areas, Straße des

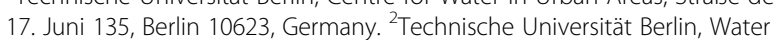
Quality Control, Straße des 17. Juni 135, Berlin 10623, Germany. ${ }^{3}$ Technische Universität Berlin, Ecological Impact Research and Ecotoxicology, Ernst-Reuter-Platz 1, Berlin 10587, Germany. ${ }^{4}$ Technische Universität Berlin, Methods of Social Research, Fraunhoferstraße 33-36, Berlin 10587, Germany. ${ }^{5}$ Berliner Wasserbetriebe, Research and Development, Cicerostraße 24, Berlin 10709, Germany. ${ }^{6}$ Berliner Wasserbetriebe, Laboratory, Motardstraße 35, Berlin 13629, Germany. ${ }^{7}$ Berliner Wasserbetriebe, Water Supply/Quality Assurance, Berlin 10864, Germany. ${ }^{8}$ Federal Environment Agency, Toxicology of Drinking Water and Pool water, Wörlitzer Platz 1, Bad Elster 08645, Germany.

${ }^{9}$ Zweckverband Landeswasserversorgung, Betriebs- und

Forschungslaboratorium, Am Spitzigen Berg 1, Langenau 89129, Germany. ${ }^{10}$ Department of Analytical Chemistry, Helmholtz Centre for Environmental Research (UFZ), Permoserstrasse 15, Leipzig 04318, Germany. ${ }^{11}$ Berlin Centre of Competence in Water, Cicerostraße 24, Berlin 10709, Germany.

Received: 21 May 2013 Accepted: 1 August 2013

Published: 8 August 2013

\section{References}

1. Schwarzenbach RP, Escher BI, Fenner K, Hofstetter TB, Johnson CA, von Gunten $U$, Wehrli B: The challenge of micropollutants in aquatic systems. Science 2006, 313:1072-1077.

2. Reemtsma T, Jekel M: Organic pollutants in the water cycle. Weinheim: Wiley; 2006.

3. Ternes TA: Occurrence of drugs in German sewage treatment plants and rivers. Water Res 1998, 32:3245-3260.

4. Joss A, Zabczynski S, Gobel A, Hoffmann B, Loffler D, McArdell CS, Ternes TA, Thomsen A, Siegrist $\mathrm{H}$ : Biological degradation of pharmaceuticals in municipal wastewater treatment: proposing a classification scheme. Water Res 2006, 40:1686-1696.

5. Bueno MJM, Gomez MJ, Herrera S, Hernando MD, Aguera A, Fernandez-Alba AR: Occurrence and persistence of organic emerging contaminants and priority pollutants in five sewage treatment plants of Spain: two years pilot survey monitoring. Environ Pollut 2012, 164:267-273.

6. Reemtsma T, Weiss S, Mueller J, Petrovic M, Gonzalez S, Barcelo D, Ventura F, Knepper TP: Polar pollutants entry into the water cycle by municipal wastewater: a European perspective. Environ Sci Technol 2006, 40:5451-5458.

7. Loos R, Gawlik BM, Locoro G, Rimaviciute E, Contini S, Bidoglio G: EU-wide survey of polar organic persistent pollutants in European river waters. Environ Pollut 2009, 157:561-568.

8. Loos R, Locoro G, Comero S, Contini S, Schwesig D, Werres F, Balsaa P, Gans O, Weiss S, Blaha L, Bolchi M, Gawlik BM: Pan-European survey on the occurrence of selected polar organic persistent pollutants in ground water. Water Res 2010, 44:4115-4126.

9. Zuhlke S, Dunnbier U, Heberer T: Detection and identification of phenazone-type drugs and their microbial metabolites in ground and drinking water applying solid-phase extraction and gas chromatography with mass spectrometric detection. J Chromatogr A 2004, 1050:201-209.

10. Grunheid S, Amy G, Jekel M: Removal of bulk dissolved organic carbon (DOC) and trace organic compounds by bank filtration and artificial recharge. Water Res 2005, 39:3219-3228.

11. Wiese B, Massmann G, Jekel M, Heberer T, Dunnbier U, Orlikowski D, Grutzmacher G: Removal kinetics of organic compounds and sum parameters under field conditions for managed aquifer recharge. Water Res 2011, 45:4939-4950.

12. Stackelberg PE, Furlong ET, Meyer MT, Zaugg SD, Henderson AK, Reissman DB: Persistence of pharmaceutical compounds and other organic wastewater contaminants in a conventional drinking-water-treatment plant. Sci Total Environ 2004, 329:99-113.

13. Stackelberg PE, Gibs J, Furlong ET, Meyer MT, Zaugg SD, Lippincott RL: Efficiency of conventional drinking-water-treatment processes in removal of pharmaceuticals and other organic compounds. Sci Total Environ 2007, 377:255-272.

14. Boehler M, Zwickenpflug B, Hollender J, Ternes TA, Joss A, Siegrist H: Removal of micropollutants in municipal wastewater treatment plants by powder-activated carbon. Water Sci Technol 2012, 66:2115-2121.

15. Yang $X$, Flowers RC, Weinberg HS, Singer PC: Occurrence and removal of pharmaceuticals and personal care products (PPCPs) in an advanced wastewater reclamation plant. Water Res 2011, 45:5218-5228.

16. Bahr C, Schumacher J, Ernst M, Luck F, Heinzmann B, Jekel M: SUVA as control parameter for the effective ozonation of organic pollutants in secondary effluent. Water Sci Technol 2007, 55:267-274.

17. Hollender J, Zimmermann SG, Koepke S, Krauss M, McArdell CS, Ort C, Singer H, von Gunten U, Siegrist H: Elimination of organic micropollutants in a municipal wastewater treatment plant upgraded with a full-scale post-ozonation followed by sand filtration. Environ Sci Technol 2009, 43:7862-7869.

18. Nakada N, Shinohara H, Murata A, Kiri K, Managaki S, Sato N, Takada H: Removal of selected pharmaceuticals and personal care products (PPCPs) and endocrine-disrupting chemicals (EDCs) during sand filtration and ozonation at a municipal sewage treatment plant. Water Res 2007, 41:4373-4382.

19. Schaar H, Clara M, Gans O, Kreuzinger N: Micropollutant removal during biological wastewater treatment and a subsequent ozonation step. Environ Pollut 2010, 158:1399-1404.

20. Seitz W, Jiang JQ, Schulz W, Weber WH, Maier D, Maier M: Formation of oxidation by-products of the iodinated $\mathrm{X}$-ray contrast medium iomeprol during ozonation. Chemosphere 2008, 70:1238-1246. 
21. Muller A, Weiss SC, Beisswenger J, Leukhardt HG, Schulz W, Seitz W, Ruck WKL, Weber WH: Identification of ozonation by-products of 4-and 5methyl-1H-benzotriazole during the treatment of surface water to drinking water. Water Res 2012, 46:679-690.

22. Igos E, Benetto E, Venditti S, Kohler C, Cornelissen A, Moeller R, Biwer A: Is it better to remove pharmaceuticals in decentralized or conventional wastewater treatment plants? A life cycle assessment comparison, Science of the Total Environment 2012, 438:533-540.

23. Wenzel H, Larsen HF, Clauson-Kaas J, Hoibye L, Jacobsen BN: Weighing environmental advantages and disadvantages of advanced wastewater treatment of micro-pollutants using environmental life cycle assessment. Water Sci Technol 2008, 57:27-32.

24. Figueira V, Vaz-Moreira I, Silva M, Manaia CM: Diversity and antibiotic resistance of Aeromonas spp. in drinking and waste water treatment plants. Water Res 2011, 45:5599-5611.

25. Witte W, Cuny C, Klare I, Nuebel U, Strommenger B, Werner G: Emergence and spread of antibiotic-resistant gram-positive bacterial pathogens. Int J Med Microbiol 2008, 298:365-377.

26. Klare I, Konstabel C, Badstubner D, Werner G, Witte W: Occurrence and spread of antibiotic resistances in Enterococcus faecium. Int J Food Microbiol 2003, 88:269-290.

27. Reemtsma T, Miehe U, Duennbier U, Jekel M: Polar pollutants in municipal wastewater and the water cycle: occurrence and removal of benzotriazoles. Water Res 2010, 44:596-604.

28. Richter D, Massmann G, Dunnbier U: Identification and significance of sulphonamides ( $p$-TSA, o-TSA, BSA) in an urban water cycle (Berlin, Germany). Water Res 2008, 42:1369-1378.

29. Hass U, Duennbier U, Massmann G: Occurrence and distribution of psychoactive compounds and their metabolites in the urban water cycle of Berlin (Germany). Water Res 2012, 46:6013-6022.

30. van der Aa NGFM, Kommer GJ, van Montfoort JE, Versteegh JFM: Demographic projections of future pharmaceutical consumption in the Netherlands. Water Sci Technol 2011, 63:825-831.

31. Heinzmann B, Chorus I: Restoration concept for Lake Tegel, a major drinking and bathing water-resource in a densely populated area. Environ Sci Technol 1994, 28:1410-1416.

32. Schimmelpfennig S, Kirillin G, Engelhardt C, Nutzmann G, Dunnbier U: Seeking a compromise between pharmaceutical pollution and phosphorus load: management strategies for Lake Tegel. Berlin, Water Res 2012, 46:4153-4163

33. Huckele S, Track T: Risk management of emerging compounds and pathogens in the water cycle (RiSKWa). Environ Sci Eur 2013, 25:1.

34. Rodil R, Quintana JB, Lopez-Mahia P, Muniategui-Lorenzo S, Prada-Rodriguez D: Multi-residue analytical method for the determination of emerging pollutants in water by solid-phase extraction and liquid chromatography-tandem mass spectrometry. J Chromatogr A 2009, 1216:2958-2969.

35. Seitz W, Schulz W, Weber WH: Novel applications of highly sensitive liquid chromatography/mass spectrometry/mass spectrometry for the direct detection of ultra-trace levels of contaminants in water. Rapid Commun Mass Spectrom 2006, 20:2281-2285.

36. Reemtsma T, Alder L, Banasiak U: A multimethod for the determination of 150 pesticide metabolites in surface water and groundwater using direct injection liquid chromatography-mass spectrometry. J Chromatogr A 2013, 1271:95-104

37. Wode F, Reilich C, van Baar P, Dunnbier U, Jekel M, Reemtsma T: Multiresidue analytical method for the simultaneous determination of 72 micropollutants in aqueous samples with ultra high performance liquid chromatography-high resolution mass spectrometry. J Chromatogr A 2012, 1270:118-126.

38. Muller A, Schulz W, Ruck WKL, Weber WH: A new approach to data evaluation in the non-target screening of organic trace substances in water analysis. Chemosphere 2011, 85:1211-1219.

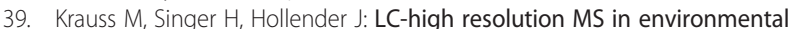
analysis: from target screening to the identification of unknowns. Anal Bioanal Chem 2010, 397:943-951.

40. Bockelmann U, Dorries HH, Ayuso-Gabella MN, de Marcay MS, Tandoi V, Levantesi C, Masciopinto C, Van Houtte E, Szewzyk U, Wintgens T, Grohmann E: Quantitative PCR monitoring of antibiotic resistance genes and bacterial pathogens in three European artificial groundwater recharge systems. App/ Environ Microbio/ 2009, 75:154-163.
41. Tao R, Ying GG, Su HC, Zhou HW, Sidhu JPS: Detection of antibiotic resistance and tetracycline resistance genes in Enterobacteriaceae isolated from the Pearl rivers in South China. Environ Pollut 2010, 158:2101-2109.

42. Patoli AA, Patoli BB, Mehraj V: High prevalence of multi-drug resistant Escherichia coli in drinking water samples from Hyderabad. Gomal J Med Sci 2010, 8:23-26.

43. Cetinkaya Y, Falk P, Mayhall CG: Vancomycin-resistant enterococci. Clin Microbiol Rev 2000, 13:686.

44. Werner G, Klare I, Fleige C, Witte W: Increasing rates of vancomycin resistance among Enterococcus faecium isolated from German hospitals between 2004 and 2006 are due to wide clonal dissemination of vancomycin-resistant enterococci and horizontal spread of vanA clusters. Int J Med Microbiol 2008, 298:515-527.

45. Lutz JK, Lee J: Prevalence and antimicrobial-resistance of Pseudomonas aeruginosa in swimming pools and hot tubs. Int J Environ Res Public Health 2011, 8:554-564.

46. Auerbach EA, Seyfried EE, McMahon KD: Tetracycline resistance genes in activated sludge wastewater treatment plants. Water Res 2007. 41:1143-1151.

47. Okeke BC, Thomson MS, Moss EM: Occurrence, molecular characterization and antibiogram of water quality indicator bacteria in river water serving a water treatment plant. Sci Total Environ 2011, 409:4979-4985.

48. Reemtsma T, Lingott J, Roegler S: Determination of 14 monoalkyl phosphates, dialkyl phosphates and dialkyl thiophosphates by LC-MS /MS in human urinary samples. Sci Total Environ 2011, 409:1990-1993.

49. Sontheimer H, Crittenden JC, Summers RS, Frick BR, Fettig J, Hörner G, Hubele G, Zimmer G: Activated Carbon for Water Treatment. Engler-BunteInstitut, Karlsruhe: DVGW-Forschungsstelle; 1988.

50. Crittenden JC, Trussel RR, Hand DW, Howe KJ, Tchobanoglous G: Water treatment - principles and design. New Jersey: Wiley; 2005.

51. Crittenden JC, Reddy PS, Arora H, Trynoski J, Hand DW, Perram DL, Summers RS: Predicting GAC performance with rapid small-scale column tests. J Am Water Works Assoc 1991, 83:77-87.

52. Corwin CJ, Summers RS: Scaling trace organic contaminant adsorption capacity by granular activated carbon. Environ Sci Technol 2010, 44:5403-5408

53. Haberkamp J, Ruhl AS, Ernst M, Jekel M: Impact of coagulation and adsorption on DOC fractions of secondary effluent and resulting fouling behaviour in ultrafiltration. Water Res 2007, 41:3794-3802.

54. Diaz-Bone R: Kulturwelt. VS-Verlag, Wiesbaden: Diskurs und lebensstil. eine diskurstheoretische erweiterung der bourdieuschen distinktionstheorie; 2010.

55. Keller R: Wissenschaftssoziologische diskursanalyse. Opladen: Leske+Budrich; 2001

56. Keller R: Diskursforschung. eine einführung für sozialwissenschaftlerlnnen Leske+Budrich: Opladen; 2003.

57. Kleinwellfonder B: Der Risikodiskurs. VS Verlag, Wiesbaden: Zur gesellschaftlichen Inszenierung von Risiko; 1996.

58. Phillipps A: Vogelgrippe \& Co. "Lebensmittelskandale" und Konsumverhalten. Eine empirische Studie, transcript: Bielefeld; 2008.

59. Berger PL, Luckmann T: Die gesellschaftliche Konstruktion der Wirklichkeit. Frankfurt: Fischer Taschenbuch Verlag; 1999.

60. Keller R: Wissenssoziologische Diskursanalyse. VS-Verlag, Wiesbaden: Grundlegung eines Forschungsprogramms; 2011.

61. WHO: Guidelines for Drinking-Water Quality: Incorporating First and Second Addenda. 3rd edition. Geneva: World Health Organization; 2008.

\section{doi:10.1186/2190-4715-25-20}

Cite this article as: Jekel et al:: Anthropogenic organic micro-pollutants and pathogens in the urban water cycle: assessment, barriers and risk communication (ASKURIS). Environmental Sciences Europe 2013 25:20. 